\title{
Judicial Body of the Southern African Development Community: Problem of Jurisdiction
}

\author{
Aslan Khuseinovich Abashidze \\ Denis Andreevich Gugunskiy \\ Aleksandra Evgen'evna Koneva
}

Aleksandr Mikhailovich Solntsev

\begin{abstract}
Department of International Law, Peoples' Friendship University of Russia, Moscow, the Russian Federation Correspondence: Denis Gugunskiy, 6 Miklukho-Maklaya str., Moscow, 117198, the Russian Federation

E-mail: gugunskiy@gmail.com
\end{abstract}

\section{Doi:10.5901/mjss.2015.v6n5s4p259}

\begin{abstract}
The history of international justice, regardless of its relatively young age, already has some peculiarities, notably long and yet difficult process of establishing the International Criminal Court, unsuccessful work experience of the Chamber for Environmental Matters of the International Court of Justice, the prospects of creating an International Environmental Court, increasing number of international criminal tribunals ad hoc, the legitimacy of creation and duration of the operation period of which raise understandable questions. In this context, another circumstance is worth mentioning: creation in 2005 of the South African Development Community (SADC) Tribunal and a unanimous decision to terminate its activities made 5 years later by the SADC Member States. This fact deserves a separate international legal analysis.
\end{abstract}

Keywords: SADC, jurisdiction, human rights, international law, African Commission, courts, tribunals

\section{Introduction}

Conceived as a sub-regional inter-governmental organization, the SADC was established in 1992 as a result of the conversion of the Southern African Development Coordination Conference (SADCC) established in 1980. SADC comprises the following 15 States: Angola, the Democratic Republic of Congo, Botswana, Zambia, Zimbabwe, Lesotho, Madagascar, Mauritius, Malawi, Mozambique, Seychelles, Namibia, Tanzania, Swaziland and South Africa.

In accordance with Art. 5 of the Treaty of the Southern African Development Community of 1992, the main objective of SADC is to strengthen cooperation in the sphere of economics, security and politics and in the sub-region. In accordance with this objective SADC is committed to improve the economic well-being of the Member States, greater integration of economics, poverty reduction and raising living standards of the Member States.

The preamble of the SADC Treaty states the need to "involve the people of the region centrally in the process of development and integration, particularly through the guarantee of democratic rights, observance of human rights and the rule of law".

According to Art. 4 of the SADC Treaty, SADC and its Member States "act in accordance with the principles of sovereign equality of all member states; solidarity, peace and security; human rights, democracy, and the rule of law; equity, balance and mutual benefit; and peaceful settlement of disputes."

Accordingly, human rights protection as a principle is an important segment of the SADC activities. In furtherance of this principle, as defined in Art. 4 of the SADC Treaty, the SADC adopted a number of human rights international instruments: The Protocol on Health of 1999, Protocol on Education and Training in SADC of 1997, SADC Protocol on Gender and Development of 2008, 1997 Declaration on Gender and Development by SADC Heads of State or Government and an Addendum to the Declaration of 1998, Charter of the Fundamental Social Rights in SADC of 2003, Maseru Declaration on the fight against HIV and AIDS of 2003, Principles and Guidelines Governing Democratic Elections of 2004, Declaration on Agriculture and Food Security 2004, and Declaration on Poverty Eradication and Sustainable Development of 2008 of 2008.

Consistent human rights advocacy position was confirmed in practice: the suspension of membership of Madagascar in SADC because of a coup in 2009 and the restoration of its membership during an emergency summit of 
the SADC on 30 January 2014 (SADC Lifts Madagascar Suspension, 2014), was justified by the commitment of SADC and its Member States to the cause of protection of democratic principles and values.

In this context, the suspension of the SADC Tribunal's activities may reasonably be qualified as a high-profile case.

\section{Literature Review}

Creation in 2005 of the South African Development Community pushed many scholars to make research on new international legal topic concerning this organization. One cannot but mention prof. Abashidze (2014), Viljoen (2012), Kaime (2004), Nathan (2011), etc. The fatal case "Michael Campbell against Zimbabwe" was analyzed in research papers of Naldi (2009), Shoko (2004), Cowell (2010), etc.

Russian professors from Institute for African Studies of the Russian Academy of Sciences such as Shubin (2012) and Khamatshin (2012) stick to the opinion that land reform in Zimbabwe has contributed to strengthening the state agricultural sector and to eliminating racial disparities in land ownership.

One of the fundamental works concerning the consequences of land reform in Zimbabwe is "The Rise and Fall of the Tribunal of the Southern African Development Community: Implications for Dispute Settlement in Southern Africa" by Erika (2013).

\section{Methodology}

The authors of the article have applied general scientific methodological approach in order to determine the scope of the research, clarify key concepts and categories related to the activities of SADC and its Judicial Body as well as highlight basic conceptual aspects of the research theme. The following general scientific methods were also applied in the study: the method of generalization, dialectics, analysis and synthesis as well as system-structural method. The authors of the research applied such special scientific methods as historical, legal comparative, legal and technical, forecasting.

\section{Results and Discussion}

SADC is not the only integration organization that has established its own judicial authority in the form of the Tribunal. The fact is that the effective resolution of disputes is one of the key aspects of management in the process of integration. Courts of regional associations, acting as institutional bodies, operate to ensure the rule of law in the framework of the process of integration of States.

In 2000, the Heads of the SADC Member States adopted the Protocol on the Tribunal and Rules thereof (Protocol on SADC Tribunal, 2000), which detail the powers of the Tribunal. Thus, under the Protocol, the Tribunal has the authority to interpret the provisions of the SADC Treaty and its Protocols. Tribunal's jurisdiction extends to all matters governed by other Agreements concluded in the framework of SADC and recognizing the jurisdiction of the Tribunal (Article 14). The Tribunal had the right to deal with interstate disputes and individuals or entities subject to the exhaustion of domestic remedies.

SADC Tribunal became operational after the inauguration of the judges, which was held in Windhoek (Namibia) on 18 November 2005. The founding documents of the SADC Tribunal have no provisions for its jurisdiction to deal with complaints about human rights violations. However, this fact did not obstruct the administration of justice by the Tribunal. Despite this fact, the Tribunal has been criticized for such an approach and for exceeding its mandate connected with the cases involving human rights violations. The main reason for such a criticism was the fact that the SADC Tribunal had been established to resolve disputes on economic and political matters within SADC and not the disputes involving human rights violations cases (Kaime, 2004).

This argument is confirmed by the fact that the Tribunal did not have a clear mechanism for enforcing its decisions. Under Art. 24 of the Protocol, the Tribunal's decision shall be binding and final. Member States are obliged to give them legal effect in national legal systems (Art. 32). According to Art. 33 of the Protocol, the summit of SADC member states can intervene in case of failure to enforce the Tribunal's decisions. In this context, some observers characterized the Tribunal as a "toothless tiger" (Ruppel \& Bangamwabo, 2009).

If we draw a parallel between the judicial bodies of other sub-regional integration associations in Africa and their jurisdiction in the field of dispute resolution in connection with the violation of human rights, we can find that, for example, the Additional Protocol amending the Protocol on the Court of ECOWAS, adopted in 2005, gives the ECOWAS Court a necessary jurisdiction to deal with the cases involving the violation of human rights in member states. The example shows that the SADC Tribunal has no clearly defined jurisdiction in dispute resolution in connection with the violation of 
human rights on the grounds that the above-mentioned competence is not enshrined in the 2000 Protocol on the SADC Tribunal.

Nevertheless, the SADC Tribunal considered a number of disputes relating to the violation of human rights, which ultimately led to a virtual suspension of its activities during the SADC summit held in Windhoek in 2010. In August 2012, the SADC summit held in Luanda (Angola), decided that the mandate of the Tribunal shall be limited to interpretation of the SADC Treaty and its Protocols with regard to disputes between SADC Member States.

\subsection{The Fatal Case "Michael Campbell Against Zimbabwe"}

Judicial ruling of the SADC Tribunal in the case of "Michael Campbell against Zimbabwe" (Mike, 2008) was the reason for the decision to limit the jurisdiction of the Tribunal.

The essence of the matter stands as follows. Ever since the declaration of independence of Zimbabwe (before 1980-Southern Rhodesia, a British colony), disputes over land issues regarding the uneven distribution of land, especially fertile land, became extremely acute.

Attempts to resolve this problem were also made before the declaration of independence. Thus, the Agreement of 1979, which was signed in London and known as the Lancaster House Agreement, stipulated that the land redistribution should be made on the basis of voluntary contracts of sale at full market price. At the same time, the UK government agreed to partially cover the expenses of land reform.

Subsequently, the Government of Zimbabwe launched a land reform, aimed at equal distribution of land between the indigenous population, which had been historically deprived of rights, and the white minority (Shoko, 2004).

In 1990, one of the provisions of the 1979 Agreement, prohibiting the confiscation of farms owned by the white, expired. In 1992, the Zimbabwe Land Acquisition Act legitimized measures aimed at compulsory acquisition of land for the purpose of resettlement, which substantially limited the constitutional right to own land. However, these measures, stipulated in the Act of 1992, were recognized by the Supreme Court of Zimbabwe as being in accordance with the Constitution.

In 1997, the British government refused the fulfillment of obligations to pay a compensation for the confiscated land.

President of Zimbabwe Robert Mugabe, trying to get support on the eve of the next presidential elections of 2000, pledged to speed up land reform to help veterans of the fight for independence to purchase land (Cowell, 2010). Having enlisted presidential support, Zimbabwe independence-era veterans came to arbitrarily occupy the farms belonging to the white minority.

Parliament of Zimbabwe supported their actions by enacting the Land Acquisition Act of 2000 and amendments to the Constitution of 2000 (Constitution of Zimbabwe Amendment, 2000). On the one hand, these legal acts provided the removal of obligations to pay the full compensation, and on the other-accelerated the process of resettlement (Naldi, 2009). As a result, the Government of Zimbabwe made all necessary payments for relocation of white settlers, but it did not compensate the real value of the land to the white farmers.

In 2001 the Zimbabwe Supreme Court considered case concerning land grab. The Court concluded that the land seizure was unlawful. Meanwhile President Mugabe in November 2001 used his "presidential powers" to make amendment to the 2001 Land Acquisition Act, retroactively (until May 2000). New provisions meant that the designated land ownership was to be transferred right away, irrespective of any court decision, to the acquiring authority and served as a ninety-day eviction notice for the former owner (penalties for non-observance included up to two years imprisonment).

The current situation became a subject of consideration submitted to the SADC Tribunal in a case initiated by Michael Campbell-a white farmer whose land had been illegally disposed of in the context of the national land reform. A group of other white farmers-who were also illegally evicted from their land and did not obtain satisfaction in the local courts-joined Campbell's claim.

A violation of the right to due legal process and racial discrimination was the base of the complaint submitted to the Tribunal by white farmers. SADC Tribunal concluded that it had jurisdiction to hear the case because the dispute concerns "human rights, democracy and the rule of law" (Abashidze, et al., 2015), which are the fundamental principles for the SADC Member States.

In 2007, the SADC Tribunal made a decision to apply provisional measures in respect of Zimbabwe, prohibiting Zimbabwe government to take any action, directly or indirectly hindering farmers from using their land. In its final decision adopted in 2008, the SADC Tribunal ruled that M. Campbell and other landowners were deprived of the right to a fair trial in their own country. Moreover, the Tribunal found that the method of implementation of the Government's reform in 
Zimbabwe was discriminatory because it restricted the rights of the white farmers. Tribunal found that the plaintiffs had a right to a fair compensation for the confiscated land (Naldi, 2009).

Land reform carried out by President Mugabe and its results attracted the attention of scientists. Russian professors from Institute for African Studies of the Russian Academy of Sciences such as Shubin (2012) and Khamatshin (2012) stick to the opinion that land reform in Zimbabwe has contributed to strengthening the state agricultural sector and to eliminating racial disparities in land ownership. They say that "... A new agrarian structure with much more variety in the size of farms and farming systems was set up." As to the resettled African farmers, they prove to be able to maintain production output at the same level as the previous landowners, while the white farmers continue to "run business", with some of them holding key positions in agricultural trade (Cowell, 2013).

\subsection{The Decision of the Tribunal: International Reaction}

The reaction of the Zimbabwe Government to SADC Tribunal's decision was strictly negative. Zimbabwe's Minister of Justice notified the SADC Tribunal in written form that he did not consider such a decision legitimate, because the Tribunal did not have appropriate jurisdiction. Zimbabwe Supreme Court also considered the decision made by the SADC Tribunal not legitimate. In connection with this, it should be recalled that at the early stages of case hearings, representative of Zimbabwe stated that Zimbabwe recognized the jurisdiction of the Tribunal (Cowell, 2013).

The plaintiffs appealed to the SADC Tribunal in order to enforce the Government of Zimbabwe to implement the decision. In response, the Minister of Zimbabwe made a number of visits to other SADC Member States seeking support among his colleagues and in order to suspend the activities of SADC Tribunal (Nathan, 2011).

During the summit of SADC in 2010 held in Windhoek, SADC heads of state and government made a decision to review the role and functions of the Tribunal of SADC, which in fact meant the suspension of its activities.

In this situation, the SADC Secretariat appealed to the British legal scholar Lorand Bartels, asking him to conduct an independent analysis of the Tribunal activities and its powers. In April 2011, the scientist presented his report (Bartels, 2011), which upheld the authority of the Tribunal, and pointed out that the decision to suspend its activities was a violation of international obligations of the Member States of SADC (Viljoen, 2012).

It should be noted that the mere fact of engaging British legal scholar as an expert to investigate the conflict in question, seems to be quite dubious, as he is a citizen of the UK, which is directly involved in this conflict.

At the SADC summit in Sandton (South Africa), held in 2011, it was decided to continue the process aimed at the revision of the SADC Tribunal's activities. Ministers of Justice and Attorneys General of the SADC Member States were instructed to prepare a report on the legal basis of Tribunal's activities and its functions.

The SADC summit in Luanda (Angola), held in 2012, adopted a resolution that established the need to adopt a new Protocol on the SADC Tribunal's activities. The resolution stated that in future the jurisdiction of the Tribunal will be limited to the interpretation of the SADC Treaty and its Protocols in cases concerning disputes arising between SADC Member States.

Such a decision could mean the factual discontinuation of activities of the Tribunal, as all the cases heard by the Tribunal were in fact disputes between individuals and legal entities; or state and the organization itself.

\subsection{Initiatives to Oppose the Suspension of the Activities of the Tribunal}

Observers admitted the possibility of opposition to such an outcome by two member states of SADC (South Africa and Botswana) (Premhid, 2013). Despite its commitment to the principles of the rule of law and human rights protection, South Africa did not oppose the idea of the actual closure of the Tribunal at the summit of SADC in Luanda. This may be due to the fact that South Africa then sought to enlist the support of Zimbabwe and other partner countries in promoting South African Minister of the Interior for the presidency of the African Union Commission (AUC).

Botswana, a State that advocated the need to adhere to international norms and obligations, did not speak against such an approach either in the course of the discussion that was initiated at the summit of SADC. However, it should be noted that Botswana also opposed the decision of the AU to ignore an arrest warrant for the extradition of Sudanese President Omar al-Bashir, issued by the International Criminal Court.

It is noteworthy that South African courts have considered a number of complaints of farmers deprived of their land in Zimbabwe, concerning the execution of the SADC Tribunal's injunctions issued in relation to the payment of compensation by the authorities of Zimbabwe and judicial foreclosure of Zimbabwe's property, located on the territory of South Africa. In connection with these appeals, the Constitutional Court of South Africa ruled that, despite the discontinuation of the SADC Tribunal, its decisions are enforceable and upheld a decision taken by the Tribunal to 
foreclose on Zimbabwe's real estate (Premhid, 2013).

In our view, the result of the case involving the complaint filed by two white farmers from Zimbabwe-Luke Tembani and Ben Frith, to the African Commission on Human and Peoples' Rights (here in after-the African Commission or ACHPR) had chances to affect the fate of the SADC Tribunal.

ACHPR took up the complaint that the decision of the Heads of the Member States concerning the discontinuation of the SADC Tribunal, violates the provisions of the African Charter on Human and Peoples Rights of 1981. According to the authors of the complaint, each of the 14 Member States of SADC, who made the above mentioned decision (Madagascar did not participate in the vote because of his membership in SADC had been suspended), should be considered a defendant in the case. Thus, this particular complaint should be recognized as a rare case where individuals had turned to the regional quasi-judicial body to recognize the responsibility of a number of States.

The authors of the complaint had already appealed to the SADC Tribunal, which upheld their claims. In the new complaint, they pointed out that consideration of their case by the African Commission gave them hope for a implementation of the decision taken by the SADC Tribunal.

In support of their position the plaintiffs referred to the violation of Art. 7, paragraph 2 (a) and Art. 26 of the African Charter on Human and Peoples' Rights of 1981 (hereinafter-the African Charter), recognizing the right to a fair trial.

At its $54^{\text {th }}$ session (October 22 to November 5, 2013), the African Commission considered the complaint and ruled that Art. 7 of the African Charter impose an obligation on States Parties regarding the right to a fair trial at the national level. Accordingly, this article of the African Charter "does not impose an international obligation on the respondent States to guarantee the right to appeal and to the consideration of the complaint by the SADC Tribunal, since the body is a regional court." (African Commission on Human and Peoples' Rights. Decision on Communication, 2013). Similarly, the ACHPR has not recognized obligations of the respondent States to ensure the independence and institutional integrity of the SADC Tribunal.

Having found no obligation to provide access to the SADC Tribunal, and having studied the relevant articles of the African Charter, The African Commission came to the conclusion that even a joint analysis of the two provisions cannot prove the existence of such an obligation.

In our opinion, special attention should be paid in this context to the observation made by the African Commission, that the plaintiffs in the complaint that they had filed, did not dispute their right to access to justice and a fair trial in the national courts. Instead, they referred to the Constitutional Court of South Africa decision, which supported their demands.

Nevertheless, the ACHPR stressed that if national courts refuse to support the rights of the applicants, they have a right to appeal to the African Commission. Accordingly, farmers from Zimbabwe have a chance to appeal to the African Commission filing a complaint about the violation by Zimbabwe of its international commitment undertaken in accordance with Art. 7 and Art. 26 of the African Charter, i.e., violation of their rights to a fair trial in the national courts.

Meanwhile, other interested parties, i.e. non-governmental organizations (NGOs ) Southern African Litigation Centre (SALC) and the Pan African Lawyers Union (PALU), also attempted to contest the decision made by the SADC member countries concerning the dissolution of the Tribunal. They appealed to the African Court on Human and Peoples' Rights (hereinafter-African Court) with a request for an advisory opinion on the legitimacy of the dissolution of the SADC Tribunal (Request for Advisory opinion, 2012). These NGOs believed that, despite the non-binding nature of this opinion, the SADC bodies will take it into account, because, as regional integration organization, SADC should strive to align its policies with the African Union. This obligation stems from the nature of Art. 3 (I) the AU Constitutive Act (Constitutive Act of the African Union, 2000), which states that it "aims to coordinate and harmonize policies between existing and future Regional Economic Communities for the gradual achievement of the goals of the Union, which also include promoting cooperation, enforcing, and protecting human and peoples' rights on the continent." (Constitutive Act of the African Union, 2000).

However, in the present context it should be understood that under the existing rules, African Court should refrain from expressing its opinion if the ACHPR has already been considering a similar complaint. African court has accepted a request of the aforementioned NGOs for an advisory opinion (Erika, 2013). Meanwhile at this date, the African Court has not proceeded to any hearings on this matter.

\section{Conclusion}

In conclusion, it must be said that in the context of international law, the decision of the SADC Member States concerning the dissolution of the Tribunal clearly undermines the progress made during the process of establishing the rule of law and protecting the rights of citizens of SADC States. Moreover, the argument of the Government of Zimbabwe that the 
decision of the Tribunal is not legitimate because it threatens the authority of the Supreme Court of the country and contradicts the Constitution of Zimbabwe, is a shaky one, because it does not meet the provisions of the Vienna Convention on the Law of Treaties of 1969 that "a State may not invoke the provisions of national law as the basis of noncompliance with international obligations" (Article 27 of the Convention). Despite the fact that Zimbabwe is not a party to the Convention, the State is bearing an international obligation in accordance with the indicated article since its provisions constitute a well-established norm of international customary law. A number of experts said that they were under the impression that while taking a decision to suspend the functioning of the Tribunal, the political leaders of the SADC Member States acted as if they had forgotten the obligation to respect international agreements concluded by them (Nkwame, 2012).

Although sovereign States are free to conclude and terminate international treaties, in this case, while deciding to suspend the activities of the Tribunal, SADC Member States stressed that in the hierarchy of values of SADC they put the sovereignty and solidarity on the first place, and the rule of law and human rights protection in the second.

SADC Member States quite obviously do not support the idea of the usefulness of the regional court and are not ready to transfer a part of their sovereign power to this body. Such approach is connected with the fact that, according to experts, they have relatively "fragile" sovereignty which is "due to their colonial past" (Fabricius, 2013). This creates the basis for the suspicion that the idea of establishing the Tribunal was dictated not by faith in international law, but rather a desire to strengthen ties with the European donor countries. That is the reason why the SADC Member States could not assess the real impact of the Tribunal, signing the Protocol on its establishment.

Absolute priority given to the principle of sovereignty in the Southern Africa region countries prevents the establishment of regional judicial bodies. Obviously, the SADC Member States will continue to refer to their sovereignty, to limit the intervention of an international organization, namely, SADC, in the political, economic and other national processes. As a result, absolute priority given to the principle of sovereignty could undermine the principle of regional cooperation between States.

In the context of an increasingly complex and interconnected world, SADC Member States should engage in an open dialogue to reach agreement on the relations and ensure a balance between the principles of sovereignty, regional cooperation, implementation of international obligations, the rule of law and human rights protection (Muchabaiwa, 2011).

At the same time, it seems necessary to define in a more distinct way, the mandate of the judicial organ of SADC. For it is evident that the lack of a clear and convincing presentation of the SADC Tribunal's powers concerning protection of human rights in the Act establishing this body (unlike the aforementioned Additional Protocol of the Court of ECOWAS), led to the suspension of the SADC Tribunal's activities.

Despite the fact that the SADC Tribunal is currently not functioning, its decisions must be carried out by virtue of the international obligations assumed by its Member States. The ruling of the Constitutional Court of South Africa proves it. As to the sanctions for the non-conformity to the Tribunal's decisions, this question is decided the summit of the SADC Member States in accordance with Art. 33 of the SADC Treaty.

Despite the current situation around the SADC Tribunal, it is obvious to all that the promotion, respect, protection and enforcement of human rights have become one of the main criteria for assessing the economic development of societies. These aspects play an increasingly important role in regional integration communities' activities. Meanwhile, there is still hope that the participation of the African regional human rights protection mechanisms represented by the African Commission and the African Court in resolving the situation around the SADC Tribunal will make a positive contribution to the rule of law in the southern African region and strengthening the role of sub-regional mechanisms in human rights protection.

\section{References}

Abashidze, A., Gugunskiy, D., Koneva, A., Simonova, M., \& Solntsev, A. (2015). Current Problems of Interstate Cooperation of Russian Federation for the Protection of Children in Case of Disputes between Parents Living in Different States. Asian Social Science, 11, 337-342.

African Commission on Human and Peoples' Rights. Decision on Communication 409/12_Luke Munyandu Tembani and Benjamin John Freeth (represented by Norman Tjombe) v Angola and Thirteen Others. Done in Banjul, the Gambia during the 54th Ordinary Session of the African Commission on Human and Peoples Rights, 22 October to 5 November 2013 - http://www.achpr.org/files/ sessions/54th/comunications/409.12_lachpr54_409_12_eng.pdf.

Bartels, L. (2011). Review of the Role, Responsibilities and Terms of Reference of the SADC Tribunal. Final Report, 6. Retrieved from http://ru.scribd.com/doc/115660010/WTIA-Review-of-the-Role-Responsibilities-and-Terms-of-Reference-of-the-SADC-TribunalFinal-Report

Constitution of Zimbabwe Amendment (No. 16) Act. (2000). Retrieved from http://www.parlzim.gov.zw/attachments/article/56/ 
constitution.pdf

Constitutive Act of the African Union. (2000). Retrieved from http://www.achpr.org/files/instruments/au-constitutive-act/au_act_2000_ eng.pdf

Cowell, F. (2010). The suspension of the Southern African Development Community Tribunal: A threat to human rights. Retrieved October 17, 2010, from http://www.consultancyafrica.com/index.php?option=com_content\&view=article\&id=583:the-suspensionof-the-southern-african-development-community-tribunal-a-threat-to-human-rights\&catid=91:rights-in-focus\&ltemid=296.

Cowell, F. (2013). The Death of the Southern African Development Community Tribunal's Human Rights Jurisdiction. Human Rights Law Review, 13, 153-165.

Erika de, W. (2013). The Rise and Fall of the Tribunal of the Southern African Development Community: Implications for Dispute Settlement in Southern Africa. ICSID Review, 28, 45-63.

Fabricius, P. (2013). Selfish JZ allowed Mugabe to kill SADC Tribunal. Retrieved March 3, 2013, from http://www.iol.co.za/news/africal selfish-jz-allowed-mugabe-to-kill-sadc-tribunal-1.1479714\#.UgDJ 5JM-Ex

Kaime, T. (2004). SADC and Human Rights: Fitting Human Rights into the Trade Matrix. African Security Review, 13 (1), 109.

Khamatshin, A. D. (2012). Agricultural sector of Zimbabwe: Collapse or rise? Asia and Africa today, 11.

Mike Campbell (Pvt) Limited and Others v Zimbabwe // AHRLR 199 (SADC 2008) - http://www1.chr.up.ac.za/index.php/human-rightsnews/509-zimbabwe-mike-campbell-pvt-limited-and-others-v-zimbabwe-2008-ahrlr-sadc-2008.html.

Muchabaiwa, B. (2011). Regionalism, sovereignty threaten SADC. Retrieved March 29, 2011, from http://sap4africa.net/news/ regionalism-sovereignty-threaten-sadc

Naldi, G. J. (2009). Mike Campbell (Pvt) Ltd et al v The Republic of Zimbabwe: Zimbabwe's land reform Programme Held in Breach of the SADC Treaty. Journal of African Law, 53, 305.

Nathan, L. (2011). Solidarity Triumphs over Democracy -The Dissolution of the SADC Tribunal. Development Dialogue. Retrieved from http://www.dhf.uu.se/publications/developmentdialogue/dd57/

Nkwame, M. (2012). Tanzania: Court to Determine Authenticity of SADC Tribunal Suspension. Tanzanian Daily News. Retrieved November 30, 2012, from http://allafrica.com/stories/201211 300078.html

Premhid, K. (2013). Bob Fights Back: Robert Mugabe and the Sadc Tribunal. Retrieved July 11, 2013, from http://voices.news24.com/ kameel-premhid/2013/07/bob-fights-back/\#.Ud7nip00LBw.email

Protocol on Tribunal in Southern African Development Community and Rules of Procedure of the Southern African Development Community Tribunal. Retrieved from http://www.sadc.int/files/1413/5292/8369/Protocol_on_the_Tribunal_and_Rules_thereof 2000.pdf

Request for Advisory opinion of the African Court on Human and Peoples' Rights. Retrieved from http://www.southernafricalitigation centre.org/1/wp-content/uploads/2012/11/Request-for-Advisory-Opinion-before-AfCHPR.pdf

Ruppel, O. C., \& Bangamwabo, F. X. (2009). The SADC Tribunal: A Legal Analysis of its Mandate and Role in Regional Integration. Monitoring Regional Integration in Southern Africa Yearbook, 8, 179.

SADC Lifts Madagascar Suspension. Retrieved Jan 30, 2014, from http://www.sadc.int/news-events/news/sadc-lifts-madagascarsuspension/

Shoko, T. (2004). My bones shall rise again: war veterans, spirits and land reform in Zimbabwe. African Studies Centre. Leiden. Retrieved from http://www.ascleiden.nl/Pdf/workingpaper68.pdf

Shubin, V. G. (2012). Zimbabwe: Crisis has been overcome? Asia and Africa today, 6.

Viljoen, F. (2012). International Human Rights Law in Africa (p. 502). Oxford: Oxford University Press. 